ISSN 1112-9867

http://www.jfas.info

\title{
E-LEARNING ACCEPTANCE BASED ON TECHNOLOGY ACCEPTANCE MODEL
}

\section{(TAM)}

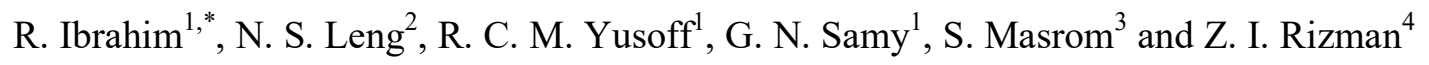 \\ ${ }^{1}$ Advanced Informatics School, Universiti Teknologi Malaysia, Kuala Lumpur, Malaysia \\ ${ }^{2}$ Faculty of Applied Science and Computing, Tunku Abdul Rahman University College, Johor, \\ Malaysia \\ ${ }^{3}$ Faculty of Computer and Mathematical Sciences, Universiti Teknologi MARA, Tapah, Perak, \\ Malaysia \\ ${ }^{4}$ Faculty of Electrical Engineering, Universiti Teknologi MARA, 23000 Dungun, Terengganu, \\ Malaysia
}

Published online: 05 October 2017

\begin{abstract}
E-learning is regarded as a mandatory teaching and learning approach in higher education worldwide. Despite its importance and popularity, several issues on its use and effectiveness still remain. Universities are facing problems oflow e-learning usage among students and even academic staffs. This study investigate students' acceptance of e-learning in university using modified TAM model consists of six constructs namely instructor characteristics, computer self-efficacy, course design, perceived usefulness, perceived ease of use and intention to use. Data were collected with 95 undergraduate students at Tunku Abdul Rahman University College (TARUC), Johor. Structural Equation Modeling (SEM) was used to analyze the data. Results shown that computer self-efficacyhas significantly effects ease of use, while perceived ease of use significantly affectsintention to use e-learning.
\end{abstract}

Keywords: e-learning; technology acceptance; TAM.

Author Correspondence, e-mail: iroslina.k1@utm.my

doi: http://dx.doi.org/10.4314/jfas.v9i4s.50 


\section{INTRODUCTION}

The online learning or better known as e-learning are implemented in almost all higher education institutions all over world from the last 15 to 20 years in general. It has taken over the traditional teaching and learning approaches since then whereby students are able to use an online system that manage courses, materials, discussion and assignments and test through the internet. Universities all over the world have spent millions of dollars to build and maintain their e-learning systems. Among the popular online learning systems are Moodle and Blackboard. Some universities use their self-developed e-learning systems. It is important to have more understanding on why students use (or not use) e-learning to ensure its implementation are fully optimize $[1-2,29]$.

E-learning or online learning is defined as the usage of the Internet connection to improve the delivery of teaching materials, communication and collaboration between learners and instructors in a virtual environment. The implementation of e-learning is widely accepted due to its tremendous opportunities to connect students and teachers especially with the advancement of internet infrastructure and capability, growing demands of flexible education and preferences of younger generations of learners. Furthermore, e-learning also offers face-to-face interaction with the instructors in the universities. Due to the prospective educational and cost benefits, e-learning has gained its importance from many parties including educational institutions, educational software developers and business organizations [1]. Universities in Malaysia also keeping up with the development by implementing e-learning technology in their education systems [2-3, 30].

E-learning has open opportunities for both educational sectors as well as business sector. E-learning implementation was found to improve students' learning performance [4]. In [1] suggested that in the competitive educational services market, it is necessary to include the e-learning component. In addition, e-learning has become significant in businesses whereby it is used to provide economical online learning for employees [5]. Prominent benefits of e-learning include providing a convenient platform whereby learners can access their learning course materials at any time, learners do not need to meet at the same place and group collaboration tools [36] such as forums and discussions board allows members to work together $[6,31]$.

\section{REVIEW OF LITERATURES}

Researches on e-learning were growing significantly from many years ago due to its importance and implementation at universities all over the world. Despite may research were 
done, the issues and challenges of successful e-learning implementation are still remains as suggested in several studies [2-3, 10]. Among the issue of e-learning are high of failure rates for e-learning courses [32], factors that affect student success in using e-learning [10, 33], student satisfaction factors with e-learning such as design clarity, interaction with the instructors and active discussion on the course [34].

Issues in most universities whom implement e-learning are reluctant of use among certain staffs and students. Many reasons contribute to the scenario, therefore, it is important investigate deeper into the issues that contribute to the scenario including understanding the user preferences and problems that they might encounter during the use activities. As discussed in many studies $[6,35]$, understanding the user's preferences and characteristics are the critical issue in improving e-learning usage and effectivenesssuggested the elements need to be considered for an effective e-learning which are environmental characteristics, environmental satisfaction, learning activities and learners' characteristics. Environmental characteristics and satisfaction also contributes to the level of e-learning usage [6]. In addition, understanding of user's attitudes also facilitates the design of e-learning environments. Apart from that, methods for assessment in el-learning are also important in success of use [35] together with learner's self-efficacy, multimedia formats and interaction environments.

Another study [10] suggested that motivation plays an important role in ensuring effective use and success e-learning. Factors of individual attitudes and expectation, clear direction and reward and recognition are noted as the notable factors for e-learning motivation. It was recommended three factors of a success e-learning namely instructor characteristics, student characteristics, technology characteristics and support as the indicators for success of e-learning. Extension of the technology acceptance model by suggesting perceived credibility as one of the important indicators for e-learning use together with perceived usefulness, perceived ease of use and computer self-efficacy [9].

It was also suggested that the dimension of for assessing the impacts of e-learning among employee includes educational technology, motivation, educational content and attitudes [37]. Educational technology consists of learning system quality, availability of systems and knowledge use of the system, technical support system, easy to use system and user friendliness. Educational content includes the dimensions of content quality, content quantity of learning, spatial and temporal flexibility, effectiveness of content and working groups. Motivation variable consist of organizational promotes, internal knowledge, promote andfinancial motives. Attitudes include the factors of internet use skills, personal experience, self-confidence and anxiety. The model presented in Fig. 1. 


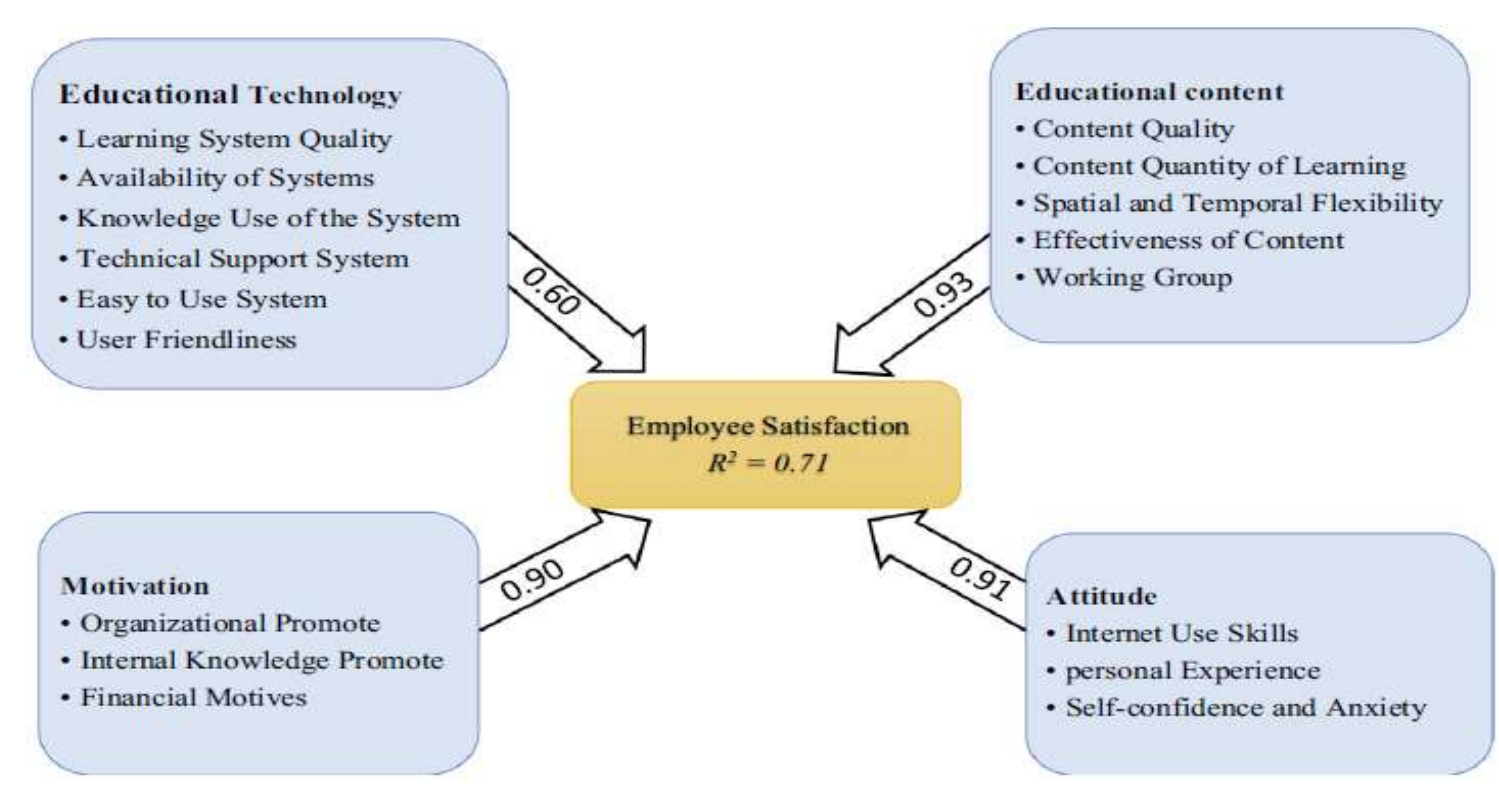

Fig.1. Dimensions for employee satisfaction in using e-learning[37]

Despite many e-learning initiatives and investment were done in recent years, it success is still the issue of discussion. It is important to measure the critical success factors related to e-learning to ensure its value of investments. Among the success factors discussed were student characteristics, instructor characteristics, learning environment, instructional design and support $[10,32]$. It was found that two most important success factors were regarded as those related to student and instructor characteristics [32]. Furthermore, it was suggested that instructor knowledge with learning technologies and student knowledge of computer systems as well as technical infrastructure are the important factors for e-learning success. Thus, the need for more investigation and exploration are always occur due to dynamic features of e-learning and implementation. In addition, the diverse features of e-learning systems itself together with various type of policy and implementation strategies also contribute to the research needs. Deeper and more thorough understanding on e-learning use will help to improve current implementation and effectiveness of e-learning.

Literatures covering on e-learning research are widely available with investigation were done form various perspectives with regards to understand how to effectively implement e-learning systems. This includes investigation on effectiveness [6-7], students' satisfaction [6, 8], acceptance [3, 9] and success factors [10]. Previous researches have discussed several problems on e-learning acceptance including poor user technology acceptance in workplace and the ineffectiveness of e-learning. In [11], the authors reveal that there is an increasing evidence that organizations' productivity has reduced because of the poor technology acceptance by organizations' staff although computers have become common at workplaces. 
The problem of the underused of e-learning application remains even through e-learning has been proven to benefit organizations and educational establishments [12].In [11] quoted a research done in Taiwan on 67 women and 89 men at Hsin-Chu Science-based Industrial Park concluded that women's rating of computer self-efficacy, perceived usefulness, perceived ease of use and behavioral intention to use e-learning are lower than men's.

Despite many research on e-learning were done all over the world, it is important to investigate the factors that affect the use of e-learning at a specific learning institutions due to different way of implementation such as the content presentation, different student background, instructors teaching style, learning cultures as well as e-learning support provided by the institutions $[3,24]$. In addition, in [12] claimed that e-learning success is depends on the execution of an educational model that meets student's requirement and educational objectives. Therefore, it is a complex task which involves multidisciplinary fields to design good e-learning systems $[1,20]$.

E-learning self-efficacy, subjective norm and system accessibility are three organizational factors considered as the external variables which influence perceived usefulness, perceived ease of use, e-learning attitude and intention to use e-learning [12]. The researcher further concluded that both e-learning self-efficacy and subjective norm have positive effects on e-learning attitude and the intention to use e-learning. In addition, the researcher also claimed that TAM is a useful model which can assist in understanding behavioral intention to use e-learning. Study conducted using survey on students to assess the application of TAM to the e-learning [3] concluded that a positive view of technology's usefulness is important to encourage individual intention to the use technology and perceived ease of use has a significant influence on the perceived usefulness.In[14], the studyapplied six dimensions (student dimension, instructor dimension, course dimension, technology dimension, design dimension and environment dimension) to investigate the important factors that influence learners' satisfaction in e-learning. The finding of the study concluded that design dimension has a positive effect on the leaners' satisfaction in e-learning.

\section{METHODOLOGY}

\subsection{Research Model and Hypothesis}

The purpose of this study is to investigate students' acceptance of e-learning in higher education. The proposed model of students' e-learning acceptance was mainly based on Technology Acceptance Model (TAM). The proposed model of this study consists of six constructs: instructor characteristics, computer self-efficacy, course design, perceived 
usefulness, perceived ease of use and intention to use e-learning. Fig. 2 shows the proposed model.

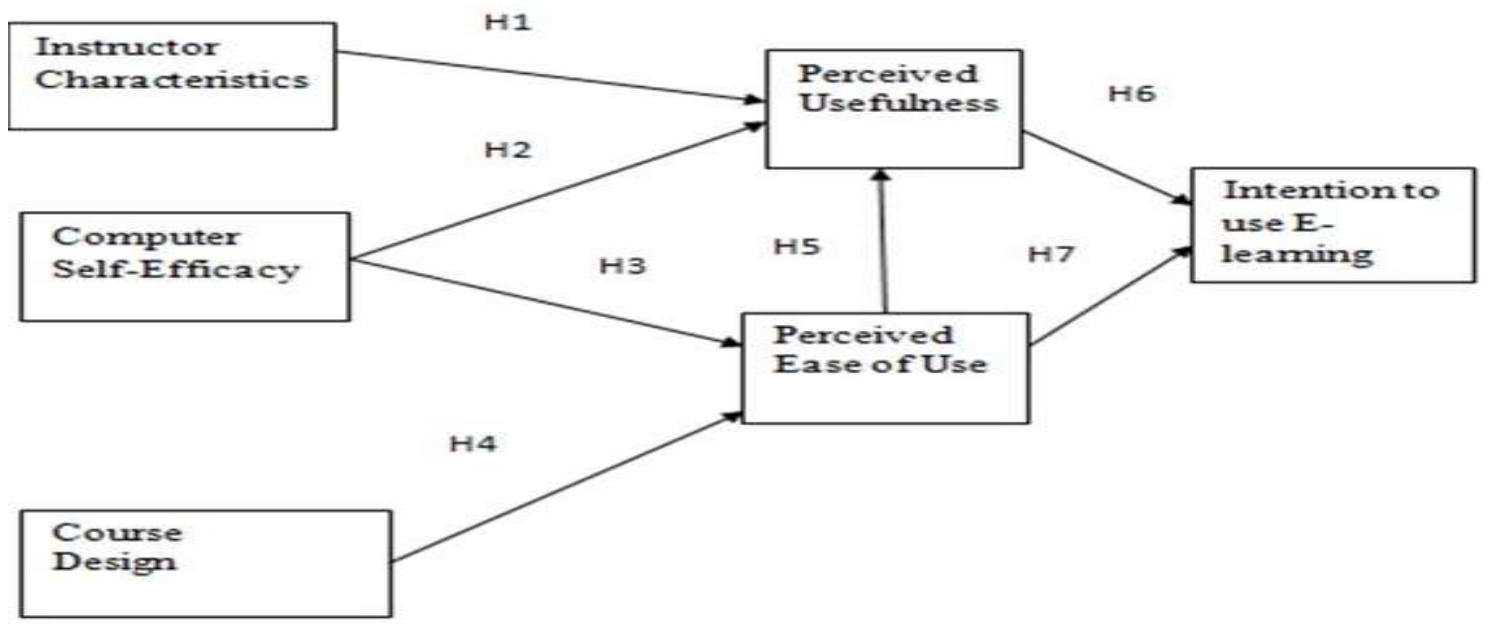

Fig.2. Research model

Instructor characteristics refer to the extent to which trainers will care, help and accommodate their students [1].In [10] found that instructor's attitude towards e-learning technology is an important factor. Additionally, previous literature indicated that positive relationships existed between instructor characteristics and perceived usefulness [1]. Thus, all these lead to the following hypotheses:

H1: Instructor characteristics have a significant effect on the perceived usefulness.

In the context of e-learning, computer self-efficacy is defined individual perceived his or her ability of using computers to complete tasks given [12].Previous research has shown that users who have more positive usefulness and ease of use beliefs, have higher computer self-efficacy[11].A significant body of research also found the importance of computer self-efficacy on the user's behavioural intention to use of technology through the factor of perceived ease of use [12]. Therefore, this study proposes the following hypotheses:

H2: Computer self-efficacy has a significant effect on the perceived usefulness.

H3: Computer self-efficacy has a significant effect on the perceived ease of use.

Three critical success factors of e-learning (instructor characteristics, student characteristics and university support) has been used in [10] to investigate the e-learning acceptance level among university students. The results revealed that course management system is one of the critical factors for e-learning acceptance. Previous researchers indicated that the design of learning contents affected the perceived ease of use [1]. Therefore, this study proposes the following hypotheses:

H4: Course design has a significant effect on the perceived ease of use. 
Evidences indicated that perceived usefulness and perceived ease of use have effects on the intention to use e-learning[11, 15]. A significant body of research found that perceived usefulness has effect on the intention to use e-learning[1,3]. In [15], the authors indicated that perceived ease of use has effect on the perceived usefulness.In [16]claimed that a person's intentions are a function of certain relevant beliefs. Therefore, this study proposes the following hypotheses:

H5: Perceived ease of use has a significant effect on the perceived usefulness.

H6: Perceived usefulness has a significant effect on the intention to use e-learning.

H7: Perceived ease of use has a significant effect on the intention to use e-learning.

\subsection{Survey Instrument Development}

Based on the relevant literature, a survey questionnaire is developed to meet the research objectives of this study. Questionnaires are divided into Part I which consists of demographic questions and Part II which consists of items for each construct. Several questions item were adapted from previous studies including[10-13, 15]. Thereafter, a few questions from each set of questionnaires were selected and organized to the constructs accordingly as presented in Appendix A. Survey items use Likert Scale from 1 as strongly disagree until 5 as strongly agree.

Appendix A. Survey items used in the study

\section{Instructor Characteristics $(\mathbf{C H})$}

CH1 I feel the instructor is keen that we use the e-learning based units.

$\mathrm{CH} 2$ We were invited to ask questions/receive answers.

CH3 The instructor encourages and motivates me to use e-learning.

CH4 The instructor is active in teaching me the course subjects via e-learning

\section{Computer Self-Efficacy (CSE)}

CSE1 Even though I only have the system manuals for reference, I am confident of using e-learning system.

CSE2 Even if I have never used the e-learning system, I am confident of using it.

CSE3 As long as I have seen someone using the e-learning system before trying it myself, I am confident of using it.

CSE4 As long as I have a lot of time to complete the job for which the software is provided, I am confident of using the e-learning system.

CSE5 As long as someone shows me how to use the e-learning system, I am confident of using it. 


\section{Course Design (CD)}

CD1 It was easy to understand the structure of the e-learning components.

CD2 It was easy to navigate through the Blackboard/course web.

CD3 The e-learning components were available all the time.

CD4 The course materials were placed on-line in a timely manner.

CD5 I perceive the design of the e-learning components to be good.

\section{Perceived Usefulness (USE)}

USE1 Advancing studies through using web-based e-learning systems can help my learning be more efficient.

USE2 Advancing studies through using web-based e-learning systems can help me acquire the information I want to acquire.

USE3 Advancing studies through using web-based e-learning systems can be helpful to my work or learning.

USE4 E-learning would improve my learning performance.

USE5 E-learning would increase academic productivity.

\section{Perceived Ease of Use (PEU)}

PEU1 Interacting with the e-learning system does not require a lot of my mental effort.

PEU2 I find the e-learning system to be easy to use.

PEU3 It is easy to become skilful at using an e-learning system.

PEU4 It would be easy for me to find information at e-learning.

\section{Intention to Use E-Learning (IU)}

IU1 I prefer e-learning to traditional learning.

IU2 I think e-learning should be implemented in other classes.

IU3 I will recommend e-learning classes to other students.

IU4 I intent to visit e-learning frequently for my course work.

IU5 I intend to use e-learning during the semester.

TARUC use Blackboard e-learning systems [17]. It is mandatory for all students and lecturers to use the systems in their teaching and learning. Screenshots of the system can be found in Appendix B. 
Appendix B. TARUC e-learning systems Blackboard screenshots

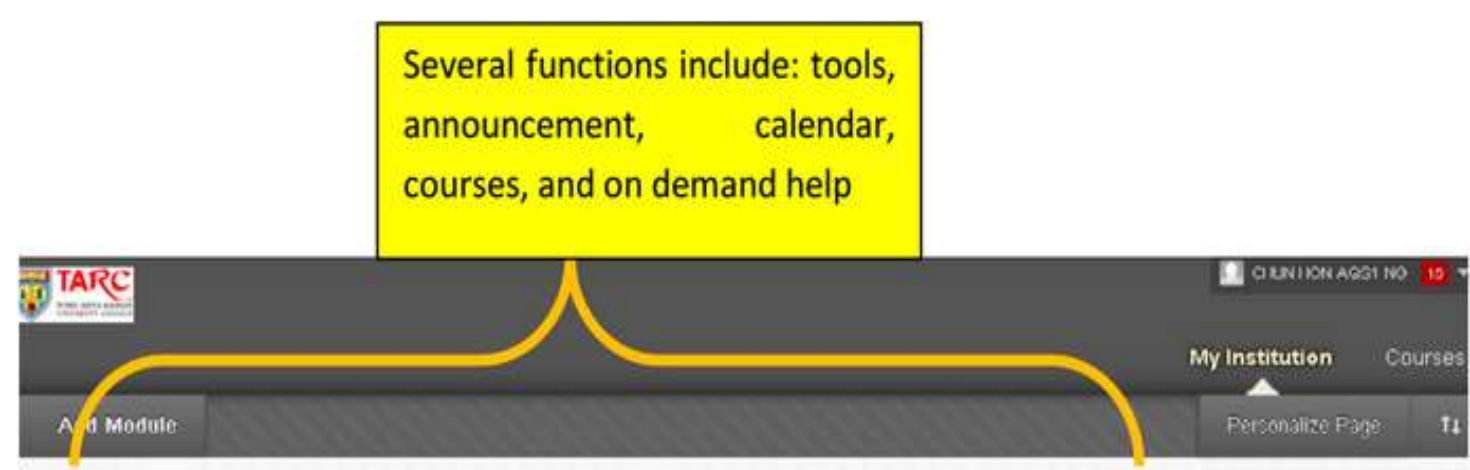

\begin{tabular}{|l|}
\hline Tools \\
\hline Announcements \\
\hline Calencar \\
\hline Tasks \\
Wy Grades \\
\hline Oend Lmail \\
User Directory \\
Address Hook \\
Personal information \\
Goals \\
\hline
\end{tabular}

My Announcements

No Institiotion Annourcements have been posted in the last 7 days.

Project \& Dis sertation

7 submission for essertasion

Reflection on Professional

Tast Pastant

TestPosted

more announcerents

My Calendar

No cakindur ewents bave been ported for the nett 7 days. ecce cavenax everts
My Courses

Courses where vou are: Student

Itbt Generat Bubetin toars

Management Thenry and Practices

Project \& Dissertation

Arinouncements

S. Subrnisssion for dissertation

Funection on professional

Announcementa

Test Posted

Test Pusled

Research Paper

Student Project Dissertations

On Demand Help and Leaming Catalor

Learn more about Blackboard Learn through our On Demand Learning Center. The On Demand Learning Center includes short, interactive video lessens catleb Uuick iutonals and snoth tucumints, Lalled Getting Statted Guides,

A 6 Collaborabsen

\section{In: 0 \\ Collaboration Sessions}

- Hanagemeat Theory and Practces

Ournatweek

Planser

Couse Dialoges

laess 09 Snst

Vicalf sound

Shasus

Preidoantets

GringFuater

M/ instruds

Hy Gads

Tols

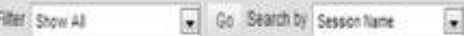
Seath

Santote

Erdost:

\begin{tabular}{|c|c|c|c|}
\hline Session lisne & Tod & Sat0de & Ensost: \\
\hline G.edure Hall & Vitha Classioum & & \\
\hline
\end{tabular}

Virtual classroom is available in the collaboration sessions. 


\subsection{Data Collection}

Data collection was done among undergraduate students at Tunku Abdul Razak University College. The questionnaire was distributed to 200 undergraduates students who are currently enroll in various study programs with 110 questionnaire were returned. All of them are having experiences with the use of e-learning systems from previous semester. Data cleaning were performed and 15 questionnaires were discarded due to incompleteness or having only one type of answer selection. Total of 95 questionnaires were used for further data analysis. Technique for determining sample size was done by following recommendation [28].

\section{RESULTS AND DISCUSSION}

\subsection{Demographic Information}

The demographic components covered gender, the faculties of the participants, program[39] that participants pursue and the year of study as presented in Table 1. The majority of participants are male (63.2\%) while the female participants consist only $36.8 \% .51 .6 \%$ of the participants came from Faculty of Accountancy, Finance and Business, 26.3\% of the participants came from Faculty of Social Science, Arts and Humanities and $22.1 \%$ of the participants came from Faculty of Applied Sciences and Computing.

The largest group of the participants reads Diploma in Business Studies (Accounting) (24.2\%). The second highest group of the participants reads Diploma in Business Studies (Business Administration) (23.2\%). The third highest group of the participants reads Diploma in Hospitality Management (Hotel Management) (18.9\%). The fourth highest group of the participants reads Diploma in Science (Information Systems Engineering) (17.9\%). The two minority groups read Diploma in Science (Internet Technology) (4.2\%) and Diploma in Business Studies (Marketing) (3.2\%). Finally, only $1.1 \%$ of the participants read Diploma in Entrepreneurship. Furthermore, about $67.4 \%$ of the participants were year 1 students while only $32.6 \%$ of the participants were year 2 students. 
Table 1. Demographic of respondents

\begin{tabular}{|c|c|c|}
\hline Item & $\mathbf{f}$ & $\%$ \\
\hline \multicolumn{3}{|l|}{ Gender } \\
\hline Male & 60 & 63 \\
\hline Female & 35 & 37 \\
\hline \multicolumn{3}{|l|}{ Faculty } \\
\hline Faculty of Applied Sciences and Computing & 21 & 22 \\
\hline Faculty of Accountancy, Finance and Business & 49 & 52 \\
\hline Faculty of Social Science, Arts and Humanities & 25 & 26 \\
\hline \multicolumn{3}{|l|}{ Study Program } \\
\hline Diploma in Science (Information Systems Engineering) & 17 & 18 \\
\hline Diploma in Science (Internet Technology) & 4 & 4 \\
\hline Diploma in Business (Studies (Accounting) & 23 & 24 \\
\hline Diploma in Business Studies (Business Administration) & 22 & 23 \\
\hline Diploma in Business Studies (Marketing) & 3 & 3 \\
\hline Diploma in Entrepreneurship & 1 & 1.1 \\
\hline Diploma in Mass Communication (Public Relations) & 7 & 7.4 \\
\hline Diploma in Hospitality Management (Hotel Management) & 18 & 18.9 \\
\hline \multicolumn{3}{|l|}{ Study Year } \\
\hline Year 1 & 64 & 67.4 \\
\hline Year 2 & 31 & 32.6 \\
\hline
\end{tabular}

\subsection{Data Analysis and Results}

Twenty-eight items were used in confirmatory factor analysis. IBM SPSS Amos 21 and the maximum likelihood technique used for data analysis included evaluating the measurement model and structure model, checking the path coefficient of variable and validating the hypothesis. Fig. 3 shows the measurement model for E-learning acceptance. This study uses several references as a guide for undertaking research process and data analysis steps [25-26]. The following three indexes were used to assess the fit of model: chi-square with degrees of freedom $\left(\mathrm{X}^{2} / \mathrm{df}\right)$, the comparative fit index (CFI) and the root mean square error of approximation (RMSEA). For a good fit of model, the chi-square with degrees of freedom should be less than or equal to 3 , the CFI should be greater than 0.9 and the root mean square error of approximation should be less than 0.08 [15]. This study obtained the CMIN value for default model is 624.452 , the CFI value for the default model is 0.785 and the RMSEA value for the default model is 0.096 [21-23]. 


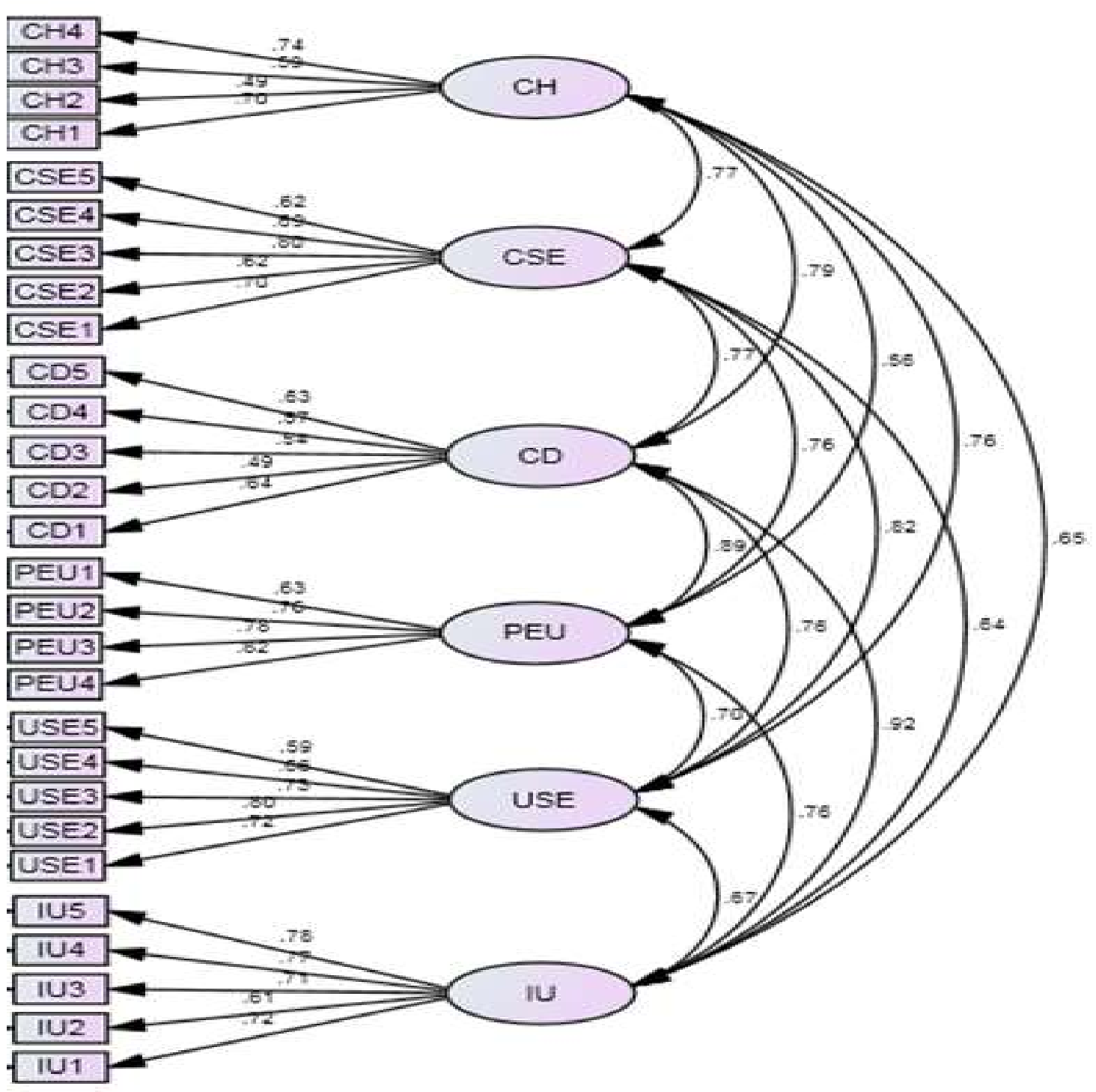

Fig.3. Measurement model

In [15] claimed that factor loading value that is greater than 0.50 indicates significant. In this study, $\mathrm{CH} 2$ was deleted since $\mathrm{CH} 2$ shows the factor loading, 0.49 below the threshold value as suggested in [15]. By removing item $\mathrm{CH} 2$ from the analysis, Table 2 shows the overall $\mathrm{X}^{2}$ value has decreased from 624.452 to 561.222 . In other words, comparing the $\mathrm{X}^{2}$ values between Model MM1 $\left(\mathrm{X}_{(334)}^{2}=561.222\right)$ and Model MM $\left(\mathrm{X}_{(335)}^{2}=624.452\right)$, the difference $\mathrm{X}^{2}$ is 63.23 . Furthermore, the CFI value has increased from 0.785 to 0.805 and the RMSEA value has decreased from 0.094 to 0.093 . However, the values of $\mathrm{X}^{2}, \mathrm{CFI}$ and RMSEA are still below the threshold [27]. Therefore, further improvement is required.

From the comparisons of the 10 models, it can be concluded that the measurement model 10 (MM10) is the final model to represent the final best-fitting model. Thus, the confirmatory factor analysis supports the hypothesized five factors except course design factors. 
Measurement model 10 (MM10) was the final measurement model with the $\mathrm{X}^{2}$ value is 161.954 and $p=0.001$, the CFI value is 0.929 and the RMSEA value is 0.072 . Summary of goodness of fit indices are presented in Table 2.

Table 2. Summary of goodness of fit

\begin{tabular}{ccccc}
\hline Test & $\begin{array}{c}\text { Item } \\
\text { Removed }\end{array}$ & $\begin{array}{c}\text { Chi-Square/CMIN } \\
\text { With Degree of } \\
\text { Freedom(Less Than 3) }\end{array}$ & $\begin{array}{c}\text { CFI } \\
\text { (Greater Than 0.90) }\end{array}$ & $\begin{array}{c}\text { RMSEA } \\
\text { (Less Than 0.08) }\end{array}$ \\
\hline MM & - & 624.452 & 0.785 & 0.096 \\
MM1 & CH2 & 561.222 & 0.805 & 0.093 \\
MM2 & CD2 & 514.131 & 0.816 & 0.093 \\
MM3 & CD3 & 465.864 & 0.829 & 0.092 \\
MM4 & CD4 & 425.246 & 0.837 & 0.092 \\
MM5 & USE5 & 331.677 & 0.889 & 0.076 \\
MM6 & CSE2 & 304.132 & 0.891 & 0.078 \\
MM7 & PEU1 & 270.908 & 0.899 & 0.077 \\
MM8 & IU2 & 246.972 & 0.900 & 0.079 \\
MM9 & CD1,CD5 & 193.184 & 0.915 & 0.076 \\
MM10 & CSE4 & 161.954 and & 0.929 & 0.072 \\
& & $\mathrm{p}=0.001$ & & \\
\hline
\end{tabular}

\subsection{Construct Reliability}

Construct reliability for measurement model is evaluated by three criteria suggested by[15]namely i) the factor loading should be greater than 0.5 ; ii) the composite reliability (CR) from each construct should be greater than 0.7 ; and iii) the average variance extracted (AVE) from each construct should be greater than 0.5 . Cronbach's alpha value that is greater than 0.70 and this indicates high reliability [18]. According to Table 3, all the values of factor loading are above 0.50 . The composite reliabilities of constructs ranged from $0.736-0.840$ are greater than 0.70 while the average variance extracted of constructs ranged from $0.484-0.621$ is less than 0.50. Lastly, the Cronbach's alpha for instructor characteristics is 0.737 , computer self-efficacy is 0.730 , perceived usefulness is 0.823 , perceived ease of use is 0.832 and intention to use e-learning is 0.834 . Thus, all the constructs are considered reliable constructs. 
Table 3. Construct reliability

\begin{tabular}{|c|c|c|c|c|c|}
\hline Factor & Item & $\begin{array}{c}\text { Factor Loading } \\
(>0.50)\end{array}$ & $\begin{array}{c}\mathrm{CR} \\
>0.70\end{array}$ & $\begin{array}{c}\text { AVE } \\
>0.50\end{array}$ & $\begin{array}{c}\text { Cronbach's } \\
\text { Alpha(>0.70) }\end{array}$ \\
\hline \multirow[t]{3}{*}{$\mathrm{CH}$} & $\mathrm{CH} 1$ & 0.72 & 0.736 & 0.484 & 0.737 \\
\hline & $\mathrm{CH} 3$ & 0.61 & & & \\
\hline & $\mathrm{CH} 4$ & 0.75 & & & \\
\hline \multirow[t]{3}{*}{ CSE } & CSE1 & 0.70 & 0.751 & 0.502 & 0.730 \\
\hline & CSE3 & 0.78 & & & \\
\hline & CSE5 & 0.64 & & & \\
\hline \multirow[t]{4}{*}{ USE } & USE1 & 0.74 & 0.827 & 0.545 & 0.823 \\
\hline & USE2 & 0.80 & & & \\
\hline & USE3 & 0.75 & & & \\
\hline & USE4 & 0.67 & & & \\
\hline \multirow[t]{3}{*}{ PEU } & PEU2 & 0.73 & 0.831 & 0.621 & 0.832 \\
\hline & PEU3 & 0.79 & & & \\
\hline & PEU4 & 0.84 & & & \\
\hline \multirow[t]{4}{*}{ IU } & IU1 & 0.69 & 0.840 & 0.570 & 0.834 \\
\hline & IU3 & 0.68 & & & \\
\hline & IU4 & 0.80 & & & \\
\hline & IU5 & 0.84 & & & \\
\hline
\end{tabular}

\subsection{Correlation between Constructs}

According to researchers in [19], 0.80 and above is classified as a strong positive correlation as presented in Table 4. In this study, the correlations between the five constructs of this study ranged from 0.501 to 0.770 . Table 5 shows the correlation between constructs.

Table 4. Strength of linear relationship [19]

\begin{tabular}{cc}
\hline Correlation Coefficient Value & Strength of Linear Relationship \\
\hline At least 0.8 & Very strong \\
0.6 up to 0.8 & Moderately strong \\
0.3 to 0.5 & Fair \\
Less than 0.3 & Poor \\
\hline
\end{tabular}


Table 5. Correlation value between constructs

\begin{tabular}{lllll}
\hline Construct 1 & 2 & 3 & 4 & 5
\end{tabular}

1. PEU (0.788)

2. $\mathrm{CH} \quad 0.501 \quad \mathbf{( 0 . 6 9 5 )}$

3. CSE $0.769 \quad 0.770 \quad(\mathbf{0 . 7 0 9})$

4. USE $0.663 \quad 0.746 \quad 0.764 \quad(\mathbf{0 . 7 3 8})$

5. IU $\quad 0.725 \quad 0.520 \quad 0.670 \quad 0.610 \quad(\mathbf{0 . 7 5 5 )}$

Note. Diagonal elements (in bold) are the square root of the average variance extracted (AVE). Off diagonal elements are the correlations between constructs.

\subsection{Structural Model and Hypothesis Testing}

Structural model is estimated after the relationship between observed variables and unobserved or latent variables of the measurement model are identified. According to the analysis presented in Fig.4, H3 and H7 are supported. H1, H2, H5 and H6 are not supported. According to the result, instructor characteristics have no effect on students' use of e-learning. This finding is inconsistent with those reported by [1], which indicates that instructor characteristics had a positive influence on the perceived usefulness of e-learning. In addition, perceived usefulness is found to have no effect on students' use of e-learning.

Computer self-efficacy has significant positive effects on perceived ease of use and the standardized path coefficients is $0.75(\mathrm{p}<0.001)$. In other words, these study shows that when the computer self-efficacy of diploma students to use e-learning is strong, the perceived ease of use e-learning is also high. Thus, it is important for university management to identify student levels of self-efficacy towards using the internet and the online learning systems. If there are lack of those levels among students, a short training or a regular training can be conducted to make sure they are well versed with internet and online applications use.

Perceived ease of use has significant positive effects on the intention to use e-learning and the standardized path coefficients is $0.57(\mathrm{p}<0.001)$. In other words, these data show that when the perceived ease of use is high, the intention to use is strong. 


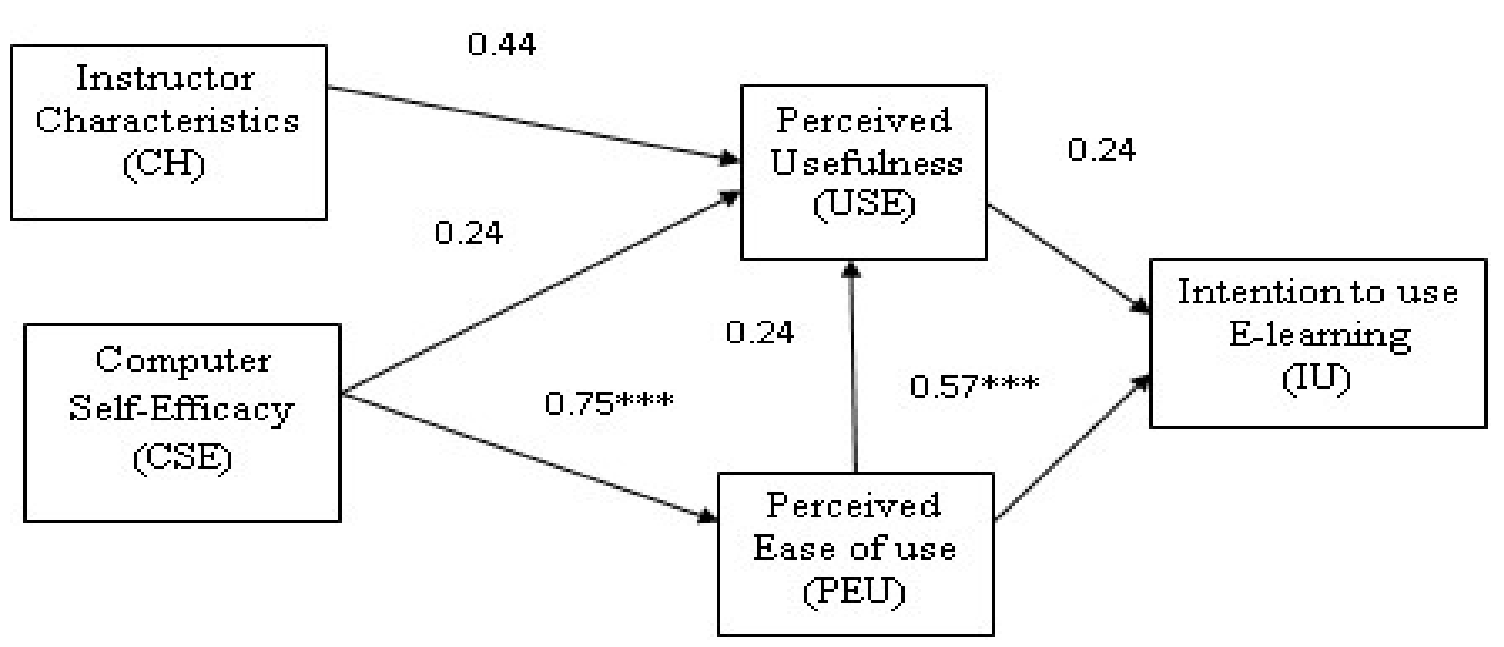

Fig.4. Standardized path co-efficient

\section{CONCLUSION}

The results of this study shown that computer self-efficacy has significant positive effects on perceived ease of use and the standardized path coefficients is $0.75(\mathrm{p}<0.001)$. The finding of this study is consistent with the study reported in [12], which indicates the importance of the computer self-efficacy on the user's behavioural intention to use of technology through the perceived ease of use. This study finds that perceived ease of use also has significant positive effects on the intention to use e-learning and the standardized path coefficients is 0.57 $(\mathrm{p}<0.001)$, which is consistent with the research results in[12]. In conclusion, the results of this study finds that computer self-efficacy, perceived ease of use and intention to use e-learning are the significant factors that affect students' use of e-learning in higher education. Thus, instructor characteristics and perceived usefulness are removed from the proposed model.

There are several limitations of this study. First, time is the main limitation whereby this study was conducted in a short period of time. The limited time spent resulted in the insufficient time used for literature review. In addition, the findings and implications of this study are obtained only from a single institution, students who currently studying at Tunku Abdul Rahman University College, Johor Branch. Thus, this limitation needs to be considered when generalizing the findings of this study to other user groups or organizations. Despite its limitations, the findings of this study provide several implications for the educational [38] institutions and educational software developers for their future improvement. 


\section{REFERENCES}

[1] Lee B C, Yoon J O, Lee I. Learners' acceptance of e-learning in South Korea: Theories and results. Computers and Education, 2009, 53(4):1320-1329

[2] Puteh M. E-learning implementation in Malaysian universities: The Universiti Teknologi Malaysia experience. In 3rd International Conference on E-learning, 2008, pp. 26-27

[3] Masrom M. Technology acceptance model and e-learning. In 12th International Conference on Education, 2007, pp. 1-10

[4] Mahdizadeh H, Biemans H, Mulder M. Determining factors of the use of e-learning environments by university teachers. Computers and Education, 2008, 51(1):142-154

[5] ŠUmak B, HeričKo M, PušNik M. A meta-analysis of e-learning technology acceptance: The role of user types and e-learning technology types. Computers in Human Behavior, 2011, 27(6):2067-2077

[6] Liaw SS. Investigating students' perceived satisfaction, behavioral intention, and effectiveness of e-learning: A case study of the Blackboard system. Computers and Education, 2008, 51(2):864-873

[7] Law K M, Lee V C, Yu Y T. Learning motivation in e-learning facilitated computer programming courses. Computers and Education, 2010, 55(1):218-228

[8] Swan K. Virtual interaction: Design factors affecting student satisfaction and perceived learning in asynchronous online courses. Distance Education, 2001, 22(2):306-331

[9] Ong C S, Lai J Y, Wang Y S. Factors affecting engineers' acceptance of asynchronous e-learning systems in high-tech companies. Information and Management, 2004, 41(6):795-804

[10]Selim H M. Critical success factors for e-learning acceptance: Confirmatory factor models. Computers and Education, 2007, 49(2):396-413

[11] Ong CS, Lai JY. Gender differences in perceptions and relationships among dominants of e-learning acceptance. Computers in Human Behavior, 2006, 22(5):816-829

[12]Lee Y H, Hsieh Y C, Ma C Y. A model of organizational employees'e-learning systems acceptance. Knowledge-Based Systems, 2011, 24(3):355-366

[13]Park S Y. An analysis of the technology acceptance model in understanding university students' behavioral intention to use e-learning. Journal of Educational Technology and Society, 2009, 12(3):150-162

[14]Sun P C, Tsai R J, Finger G, Chen Y Y, Yeh D. What drives a successful e-Learning? An empirical investigation of the critical factors influencing learner satisfaction. Computers and Education, 2008, 50(4):1183-1202 
[15]Chen H R, Tseng H F. Factors that influence acceptance of web-based e-learning systems for the in-service education of junior high school teachers in Taiwan. Evaluation and Program Planning, 2012, 35(3):398-406

[16]Fishbein M., Ajzen I. Belief, attitude, intention and behavior: an introduction to theory and research.Massachusetts: Addison-Wesley, 1977

[17] Tunku Abdul Rahman University College (TARUC).About Tunku Abdul Rahman University College. 2017,http://www.tarc.edu.my/about/about.htm

[18]Nunnally J. C. Psychometric theory. New York: McGraw-Hill, 1978

[19] Chan Y H. Biostatistics 104: Correlational analysis. Singapore Medical Journal, 2003, 44(12):614-619

[20]Alnsour J, Meaton J. Factors affecting compliance with residential standards in the city of Old Salt, Jordan. Habitat International, 2009, 33(4):301-309

[21]Blunch N. Introduction to structural equation modeling using IBM SPSS statistics and Amos. California: SAGE Publishing, 2012

[22]Brown T.A. Confirmatory factor analysis for applied research. New York: Guilford Press, 2015

[23]Byrne B.M. Structural equation modeling with AMOS: Basic concepts, applications, and programming. Abingdon: Routledge, 2013

[24]Cheung R, Vogel D. Predicting user acceptance of collaborative technologies: An extension of the technology acceptance model for e-learning. Computers and Education, 2013, $63: 160-175$

[25]Chua Y.P. Mastering research methods. Kuala Lumpur: McGraw-Hill,2012

[26]Gravetter F. J., Wallnau L. B. Statistics for the behavioral sciences.Boston: Cengage Learning, 2013

[27]Hafiz B, Shaari J A. Confirmatory factor analysis (CFA) of first order factor measurement model-ICT empowerment in Nigeria. International Journal of Business Management and Administration, 2013, 2(5):81-88

[28]Krejcie R V, Morgan D W. Determining sample size for research activities. Educational and psychological measurement, 1970, 30(3):607-610

[29] Omidinia S, Masrom M, Selamat H. Review of e-learning and ICT infrastructure in developing countries (case study of Iran). American Journal of Economics and Business Administration, 2011, 3(1):120-125

[30] Shih M, Feng J, Tsai C C. Research and trends in the field of e-learning from 2001 to 2005: A content analysis of cognitive studies in selected journals. Computers and Education, 
2008, 51(2):955-967

[31]Thompson T L, MacDonald C J. Community building, emergent design and expecting the unexpected: Creating a quality eLearning experience. The Internet and Higher Education, 2005, 8(3):233-249

[32] Alhabeeb A, Alhabeeb A, Rowley J, Rowley J. Critical success factors for eLearning in Saudi Arabian universities. International Journal of Educational Management, 2017, 31(2):131-147

[33]Bouhnik D, Marcus T. Interaction in distance-learning courses. Journal of the Association for Information Science and Technology, 2006, 57(3):299-305

[34] Swan K. Virtual interaction: Design factors affecting student satisfaction and perceived learning in asynchronous online courses. Distance Education, 2001, 22(2):306-331

[35]Liaw S S, Huang H M. Developing a collaborative e-learning system based on users' perceptions. In International Conference on Computer Supported Cooperative Work in Design, 2006, pp. 751-759

[36]Liaw S S. Understanding computers and the Internet as a work assisted tool. Computers in Human Behavior, 2007, 23(1):399-414

[37]Navimipour N J, Zareie B. A model for assessing the impact of e-learning systems on employees' satisfaction. Computers in Human Behavior, 2015, 53:475-485

[38]Fauzi A, Rizman Z I. Field trip education approach beyond classroom: Microwave course case. Mediterranean Journal of Social Sciences, 2015, 6(4):89-94

[39]Nordiana M, Nurbaiti W, Zairi I R, Mohd A A, Mohd A A, Ermeey A. K, Gopala K S N.Industry's feedback of new diploma program in industrial engineering. World Applied Sciences Journal, 2013, 23(23):103-108

\section{How to cite this article:}

Ibrahim R, Leng N S, Yusoff R C M, Samy G N, Masrom S, Rizman Z I. E-learning acceptance based on technology acceptance model (tam). J. Fundam. Appl. Sci., 2017, 9(4S), 871-889. 